\section{Phytoremediation of chromium: distribution and speciation of chromium in Typha angustifolia}

\author{
Viky Vidayanti, Devi N. Choesin, \\ Iriawati Iriawati
}

School of Life Sciences and Technology, Institut Teknologi Bandung, Indonesia

\begin{abstract}
Chromium $(\mathrm{Cr})$, especially in hexavalent chromium $[\mathrm{Cr}(\mathrm{VI})]$ may contaminate water or soil and cause detrimental effects, as it is potentially carcinogenic and teratogenic. Phytoremediation using plants such as Typha angustifolia provides an alternative approach for handling $\mathrm{Cr}$ waste. The objective of this study was to determine the mechanism of $\mathrm{Cr}$ accumulation in $T$. angustifolia. Hydroponic media containing $T$. angustifolia was added with 0, 1, 5, 10 and $20 \mathrm{ppm}$ of $\mathrm{Cr}$ (VI) $\left(\mathrm{K}_{2} \mathrm{Cr}_{2} \mathrm{O}_{7}\right)$. After 15 days of treatment, distribution and speciation of $\mathrm{Cr}$ in roots and shoots of T. angustifolia were analyzed using XAS and $\mu$-XRF. Results showed that $\mathrm{Cr}$ was detected in almost all parts of root and shoot at different intensities. Intensities of $\mathrm{Cr}$ was higher in roots (especially in the vascular bundle) than in shoot. Cr speciation in the root and shoot was found as trivalent chromium [Cr(III)] which formed as a result of $\mathrm{Cr}(\mathrm{VI})$ reduction. Based on the patterns of $\mathrm{Cr}$ distribution and speciation, results of this study suggest that $T$. angustifolia in this study does not reduce $\mathrm{Cr}(\mathrm{VI})$ to become $\mathrm{Cr}(\mathrm{III})$ inside the plants.
\end{abstract}

\section{Introduction}

EtOAcChromium $(\mathrm{Cr})$, especially in the hexavalent form $[\mathrm{Cr}(\mathrm{VI})]$, is the second most commonly found waste element in the world, after arsenic (Ar). ${ }^{1}$ Approximately $90 \%$ of this waste originates from metallurgical industries, 5\% from refractories and foundries, and $5 \%$ from other chemical industries. ${ }^{2}$ The level of $\mathrm{Cr}$ toxicity depends on its valence, i.e., Cr with a valence of six $[\mathrm{Cr}(\mathrm{VI})]$ is more toxic than $\mathrm{Cr}$ with a valence of three [Cr(III)].

EtOAcIndonesia as a developing country has 78,221 sites with possible exposure to $\mathrm{Cr}(\mathrm{VI}){ }^{3}$ This statement is in line with data from the Ministry of IndustryIndonesia which describes a $7 \%$ increase in industrial development each year. ${ }^{4}$ Therefore, it is expected that the production of waste containing $\mathrm{Cr}$ will continue to increase and contaminate the environment, especially soil and water. Consequently, people living in certain areas of Indonesia face high possibility of health risks such as infertility, respiratory problems and birth defects which are caused by $\mathrm{Cr}(\mathrm{VI}) .^{3}$

Efforts to reduce and remove environmental contaminants have so far included the processes of precipitation, electrolysis, filtration, ion exchange and phytoremediation. However, phytoremediation is perhaps the least expensive, easiest, and most environmentally friendly approach. Phytoremediation is the technology of using plants to reduce or remove contaminants from the environment and accumulating them within the plant. ${ }^{5,6}$ Not all plants can be used as phytoremediation agents because not all of them have the required defense mechanisms against contaminants, or the ability to accumulate contaminants in less toxic forms. At present, only 450 Angiosperms are known to be heavy metal hyperaccumulators. ${ }^{7}$

EtOAcTypha is a plant genus from the Typhaceae family which is commonly used in constructed wetland systems designed to reduce and remove contaminants. Certain Typha species, such as T. angustata and T. latifolia are found to accumulate $\mathrm{Cr}$ in their roots and shoots. ${ }^{8,9}$ It is suggested that another species, T. angustifolia which is easily found in Java, Indonesia has also potential to accumulate Cr. However, more research is needed to understand the mechanism involved in $\mathrm{Cr}$ accumulation, specifically in $T$. angustifolia. Therefore, the objective of this research was to study the mechanism of $\mathrm{Cr}$ accumulation based on its distribution and speciation in T. angustifolia treated with $\mathrm{Cr}(\mathrm{VI})$ using micro X-ray fluorescence $(\mu-\mathrm{XRF})$ imaging and $\mathrm{X}$-ray absorption near-edge structure (XANES).

\section{Materials and Methods}

\section{Plant material}

EtOAcAs many as $60 \mathrm{~T}$. angustifolia plants were collected from areas free from $\mathrm{Cr}$ contamination at Eretan Kulon Indramayu, West Java, Indonesia (6'18'44.19"'S and 108 $02^{\circ} 39.93$ 'T; Figure 1). This research only used plants aged 2.5 - 3 months old. The plants were first cleaned using tap water to remove soil and clay, then acclimated in water containing commercial hydroponic nutrients ( $\mathrm{AB}$ mix). The composition of $1.6 \mathrm{ppm}$ nutrient solution consisted of $5 \mathrm{Ca}\left(\mathrm{NO}_{3}\right)_{2} \cdot \mathrm{NH}_{4} \mathrm{NO}_{3}$. $10 \mathrm{H}_{2} \mathrm{O}, \quad \mathrm{KNO}_{3}, \quad \mathrm{Fe}-\mathrm{EDTA}, \quad \mathrm{KH}_{2} \mathrm{PO}_{4}$, $\left(\mathrm{NH}_{4}\right)_{2} \mathrm{SO}_{4}, \mathrm{~K}_{2} \mathrm{SO}_{4}, \mathrm{MgSO}_{4} .7 \mathrm{H}_{2} \mathrm{O}, \mathrm{MnSO}_{4}$.
Correspondence: Viky Vidayanti, School of Life Sciences and Technology, Institut Teknologi Bandung, Jl. Ganesha 10, Bandung 40132, West Java, Indonesia

Tel.: +62.85755140272

E-mail: viky.vidayanti@students.itb.ac.id

Key words: Chromium; phytoremediation; distribution; speciation; Typha angustifolia.

Acknowledgements: the authors thank Synchrotron Light Research Institute (Nakhon Ratchasima, Thailand) for research facilities at beam line $6 \mathrm{~b}$ and 8 ; and the Institute of Research and Community Services (LPPM) of Institut Teknologi Bandung (ITB) for financial support through its 2015 Research Grant program.

Contributions: VV, collecting and analyzing the data, writing the manuscript; DNC and II, analyzing data, writing and reviewing the manuscript.

Conflict of interest: the auhtors declare no potential conflict of interest.

Funding: this research was partially funded by Institute of Research and Community Services (LPPM) of Institut Teknologi Bandung (ITB).

Received for publication: 6 September 2016 Revision received: 5 December 2016.

Accepted for publication: 5 December 2016

This work is licensed under a Creative Commons Attribution-NonCommercial 4.0 International License (CC BY-NC 4.0).

CC Copyright V. Vidayanti et al., 2017 Licensee PAGEPress srl, Italy

International Journal of Plant Biology 2017; 8:6870 doi:10.4081/pb.2017.6870

$4 \mathrm{H}_{2} \mathrm{O}, \mathrm{CuSO}_{4} .5 \mathrm{H}_{2} \mathrm{O}, \mathrm{ZnSO}_{4} \cdot 7 \mathrm{H}_{2} \mathrm{O}, \mathrm{H}_{3} \mathrm{BO}_{3}$, and $\left(\mathrm{NH}_{4}\right) 6 \mathrm{Mo} 7 \mathrm{O}_{24} \cdot 4 \mathrm{H}_{2} \mathrm{O}$. Plants were acclimated for two weeks in a greenhouse at $28-35^{\circ} \mathrm{C}, 51-70 \%$ humidity and $55.7-107.8$ KLux light intensity at noon.

\section{Chromium phytoremediation treatments}

EtOAcThe plants were treated in 1, 5, 10 , and $20 \mathrm{ppm}$ of $\mathrm{Cr}(\mathrm{VI})$ from $\mathrm{K}_{2} \mathrm{Cr}_{2} \mathrm{O}_{7}$ (Merck) for 15 days with four replications. Every treatment contained three plants with a total wet weigh of $380-400 \mathrm{~g}$. The plants were then harvested after 15 days treatment and washed using tap water and deionized water. Harvested plants were separated into root and shoot, weighed for wet biomass, and then dried at $80^{\circ} \mathrm{C}$ for 48 hours. Afterwards, samples were digested by wet ashing method and measured for $\mathrm{Cr}$ accumulation using atomic absorption spec- 
troscopy (AAS) with $357.9 \mathrm{~nm}$ to decide the preliminary and early (before the treatment) $\mathrm{Cr}$ content in the plant. ${ }^{10}$

\section{$\boldsymbol{\mu}$-XRF imaging and XANES analysis}

EtOAcFor $\mu$-XRF imaging, the root and shoot of plants were cut into small parts (measuring about $1 \mathrm{~cm}$ ), placed in an acrylic sample holder, and then placed into $\mu$-XRF detection. Dwell time per point was five seconds and step size between points was $0.05 \mathrm{~mm}$. For XANES, roots and shoots were cut into $2 \mathrm{~cm}$ pieces, put on kapton tape then placed in a sample holder for XAS detection. This study used the upper shoot part was examined. Reference materials utilized were $\mathrm{K}_{2} \mathrm{Cr}_{2} \mathrm{O}_{7}$ and $\mathrm{CrO}_{3}$ for $\mathrm{Cr}(\mathrm{VI})$; and $\mathrm{Cr}_{2} \mathrm{O}_{3}$ for $\mathrm{Cr}(\mathrm{III})$. The $\mu$ $\mathrm{XRF}$ imaging and XANES analysis were performed at beamline $6 \mathrm{~b}$ and 8 in Synchrotron Light Research Institute at Nakhon Ratchasima, Thailand. The $\mu$-XRF imaging and XANES data were analyzed using ROI imaging tools and ATHENA. ${ }^{11}$

\section{Results}

EtOAcThe $\mathrm{Cr}$ content in plants was also measured before treatments were started. Early measurements showed that the plants had $0 \mathrm{mg} / \mathrm{kg}$ total $\mathrm{Cr}$, indicating that the plants were free from $\mathrm{Cr}$ contaminant. In a preliminary experiment, total $\mathrm{Cr}$ in root and shoot was analyzed using AAS. Results showed that $\mathrm{Cr}$ concentrations were detected in both root and shoot of T. angustifolia treated with 1, 5, 10 and 20 ppm of Cr(VI). However, preliminary AAS measurements indicated that the accumulation of $\mathrm{Cr}$ in roots ( 287.16 to $4399.79 \mathrm{mg} / \mathrm{kg}$ ) was significantly higher than in the shoots (234.02 to $1157.28 \mathrm{mg} / \mathrm{kg}) \quad(\mathrm{P}>0.05)$ (Vidayanti and Choesin 2015, unpublished data).

\section{Distribution of $\mathbf{C r}$}

EtOAcThe XRF intensity was normalized by incident $\mathrm{X}$-rays and expressed with a color scale from blue to red that corresponded from lowest to highest, respectively (Figures 2 and 3). $\mu$-XRF imaging from roots treated with $\mathrm{Cr}(\mathrm{VI})$ is shown in Figure 2. Cr was detected throughout all parts of the primary root, but was primarily distributed in the center part which consists of the vascular bundle, and decreased towards the outer part. It was clearly indicated that concentration of $\mathrm{Cr}$ in the vascular bundle was higher than in other parts. It could be assumed that $\mathrm{Cr}$ was transported or translocated into the shoot through the vascular bundle, i.e., xylem. $\mathrm{Cr}$ uptake by roots could also be translocated into other tissues

and organelles. During upward translocation process, $\mathrm{Cr}$ may be transferred to the xylem through the apoplastic route. We assumed that the symplastic route to the cortex and pith may have occured. This process must be confirmed by further root cross-section analysis.
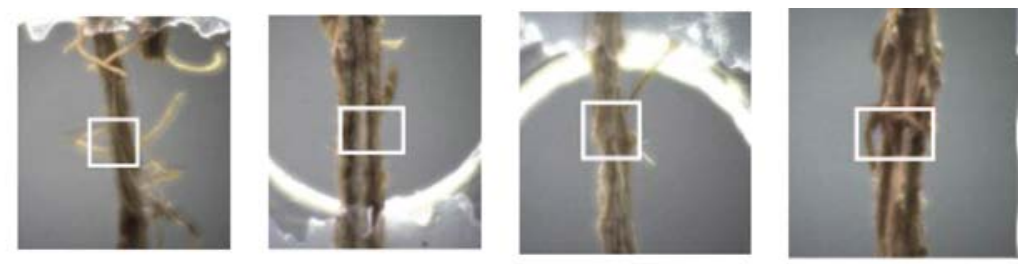
High

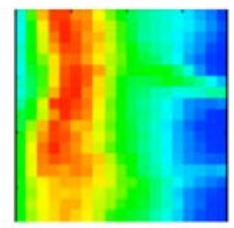

A

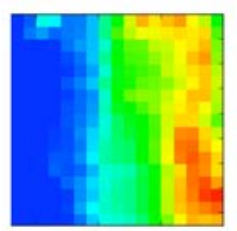

B

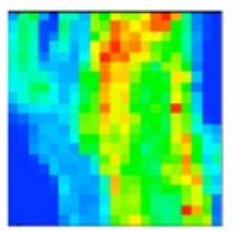

C

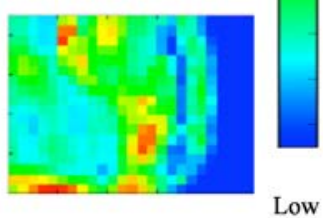

D

Figure 1. $\mu$-XRF imaging of T. angustifolia roots treated with $\mathrm{Cr}(\mathrm{VI})$ (A) $1 \mathrm{ppm}$ (B) 5 ppm (C) $10 \mathrm{ppm}$ and (D) $20 \mathrm{ppm}$. Photographs of the root treated with $\operatorname{Cr}$ (VI) (A) 1 ppm (B) 5 ppm (C) 10 ppm and (D) 20 ppm.
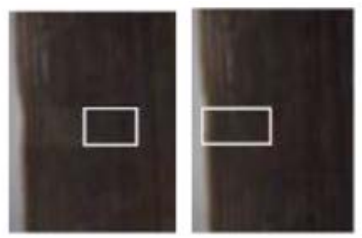

A
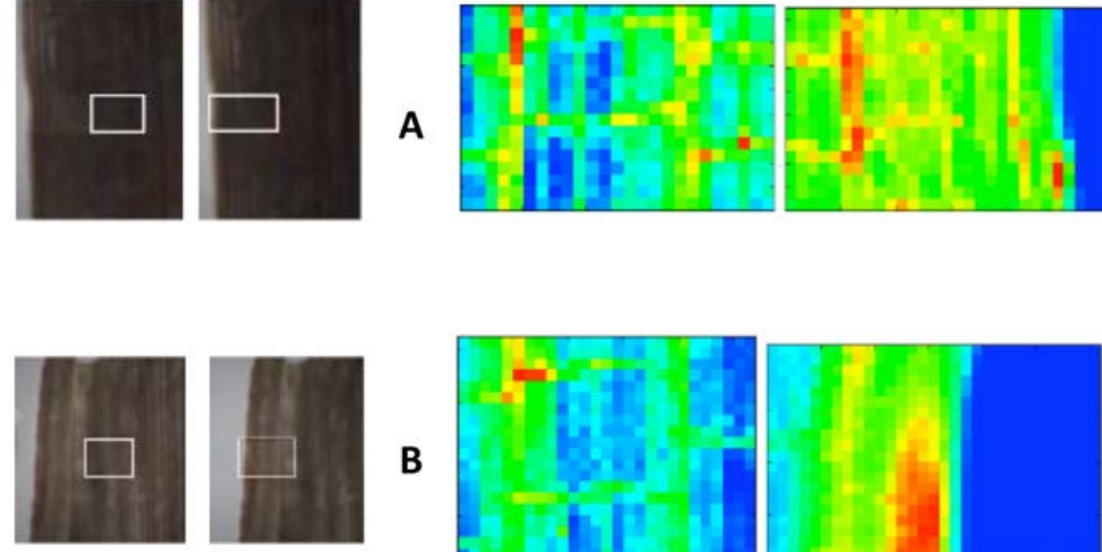

B
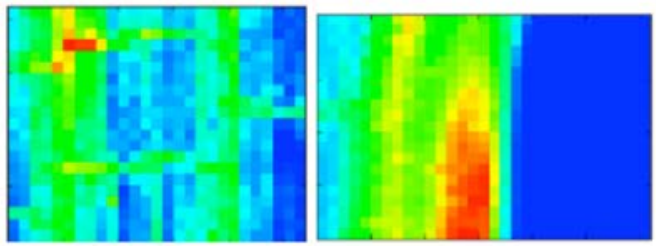

C
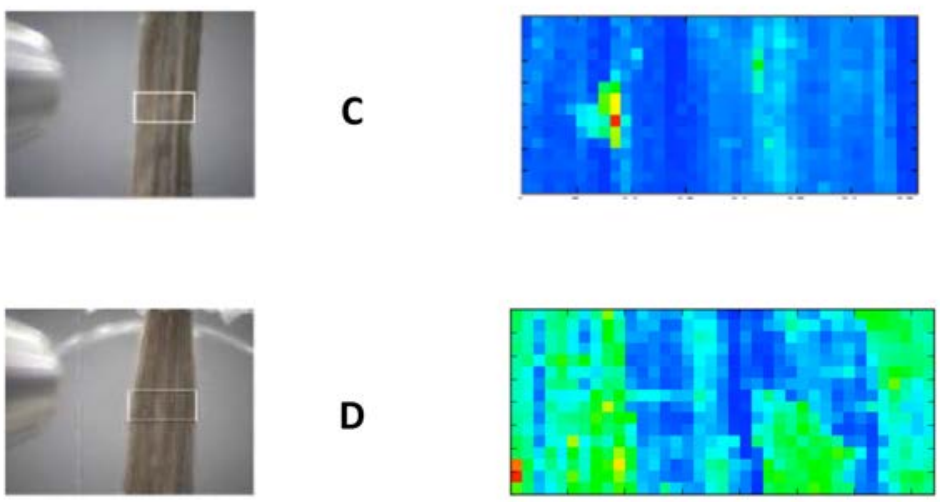

Figure 2. $\mu$-XRF imaging of T. angustifolia shoots treated with $\mathrm{Cr}(\mathrm{VI})$ (A) $1 \mathrm{ppm}$ (B) 5 ppm (C) $10 \mathrm{ppm}$ Ad (D) $20 \mathrm{ppm}$. Photographs of the shoot treated with $\mathrm{Cr}$ (VI) (A) 1 ppm (B) 5 ppm (C) 10 ppm and (D) 20 ppm. 
root to shoot may occur through the xylem and veins but cross section observations of the root are needed to confirm this. The distribution pattern of $\mathrm{Cr}$ in shoots was not as clear as that observed in roots. Cr was initially expected to accumulate in specific parts of the shoot to avoid toxic elements in photosynthetic active tissue.

\section{Speciation of $\mathbf{C r}$}

EtOAcXANES spectra of samples were compared and fitted using spectra of $\mathrm{Cr}(\mathrm{VI})$ and $\mathrm{Cr}$ (III) reference materials which has energy peaks in 6001-6020 eV and 6021$6040 \mathrm{eV}$. Figure 3 was obtained from Cr Kedge XANES spectra of root and shoot. At first, $\mathrm{Cr}$ species between root and shoot was expected to be different, and a difference was also expected among $\mathrm{Cr}$ concentration treatment. However, it was clearly illustrated that the oxidation state of accumulated $\mathrm{Cr}$ in plants treated with $\mathrm{Cr}(\mathrm{VI})$ was $\mathrm{Cr}(\mathrm{III})$.

EtOAcThe curve pattern and peak of samples was similar with the peak of $\mathrm{Cr}$ (III) reference (Figure 3). XANES fitting of the spectra for the root of plants treated with $\mathrm{Cr}(\mathrm{VI})$ exhibited features mainly consisting of $\mathrm{Cr}$ (III). This $\mathrm{Cr}$ species was also found in shoots. These results suggest that $T$. angus tifolia did not reduce $\mathrm{Cr}(\mathrm{VI})$ in its roots. This plant uptook $\mathrm{Cr}$ (III) directly from the medium, so we suggested that $\mathrm{Cr}(\mathrm{VI})$ was reduced to $\mathrm{Cr}$ (III) in the media before being uptake by roots. Afterward, $\mathrm{Cr}$ would be transported to shoot, where it is accumulated as $\mathrm{Cr}(\mathrm{III})$. That is why XANES only detected $\mathrm{Cr}(\mathrm{III})$ in the shoot.

\section{Discussion}

EtOAcCr is not known as an essential or important element for plant growth. High concentrations of $\mathrm{Cr}$ may cause detrimental effects on plants, ranging from chlorosis to death. However, small amounts of $\mathrm{Cr}$ (5 $\mathrm{mg} / \mathrm{kg}$ ) can increase nitrification rates in soil and increase the amount of nitrogen in plants. ${ }^{12}$ For plants that are able to accumulate and tolerate heavy metals, high concentrations of heavy metal in their environment will not detrimentally affect their survival. These plants are able to absorb heavy metals from the environment and accumulate them by distributing to other plant parts.

EtOAcThe concentration of $\mathrm{Cr}$ in roots observed in this study was distributed primarily in the center part, which corresponds to vascular bundles containing xylem and phloem and have an important role in transporting minerals, nutrients, and also heavy metals. ${ }^{13}$ This pattern was also observed in Sedum alfredii, in which $\mathrm{Zn}$ was distributed mainly along the xylem. ${ }^{14}$ The accumulation of $\mathrm{Cr}$ in Gynura pseudochina treated with $\mathrm{Cr}(\mathrm{III})$ was also located in the stem cortex and vascular bundle. Distribution, translocation and accumulation of $\mathrm{Cr}$ in $G$. pseudochina primarily depended on the oxidation state of $\mathrm{Cr}$ and on the plant tissue. ${ }^{15}$ Studies have found that roots of Typha latifolia and T. angustifolia can accumulate $\mathrm{Pb}$ and $\mathrm{Cr}$ mainly in the epidermis. ${ }^{16-18}$ Therefore, $\mathrm{Cr}$ in T. angustifolia of this study may perhaps still be in the upwards translocation and sequestration process because it was found mainly in the vascular bundle.

EtOAcThe detection of $\mathrm{Cr}$ in shoots indicate that $\mathrm{Cr}$ was transported from root to shoot. The specific tissue in which $\mathrm{Cr}$

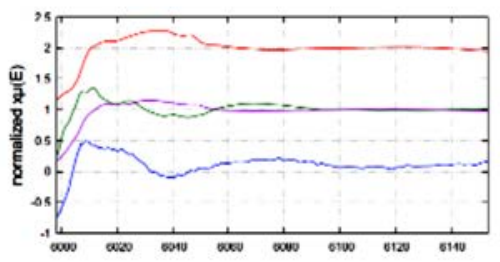

A
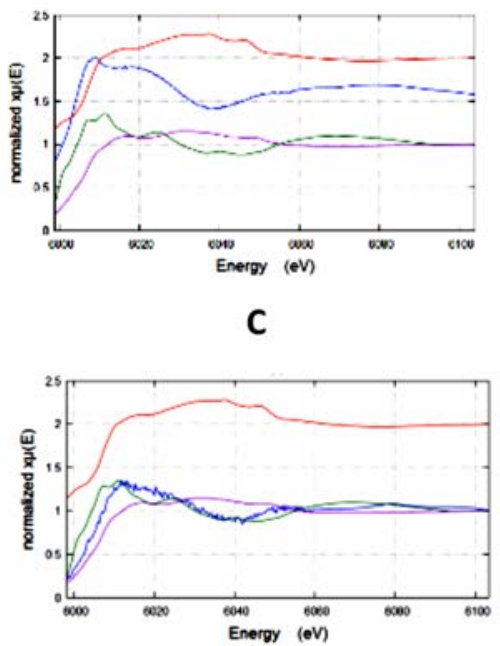

E

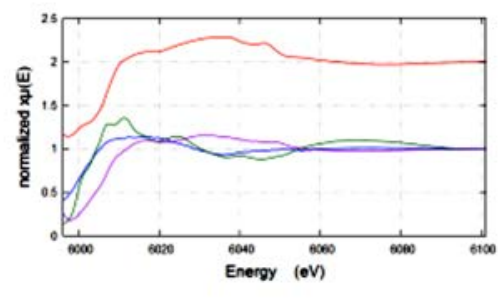

G was accumulated could not be determined based on Figure 4 and cross section observations are required to confirm it. There is a possibility that $\mathrm{Cr}$ is accumulated in tissues that are not directly involved in photosynthesis, in view of the fact that $\mathrm{Cr}$ can be toxic to the plant at even low concentrations. Therefore, $\mathrm{Cr}$ is expected to accumulate in leaf veins, to minimize damage to photosynthetic active tissue (mesophyll). The elements cadmium (Cd), cerium (Ce), copper $(\mathrm{Cu})$, lanthanium $(\mathrm{La})$, manganese $(\mathrm{Mn})$, and zinc $(\mathrm{Zn})$ are also potentially harmful to plants at high concentrations, and have been found to accumulate in the leaf veins of Helianthus annuus. ${ }^{19}$ Not all of hyperaccumulator plants accumulate toxi-

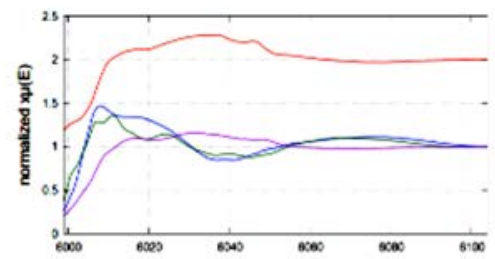

B
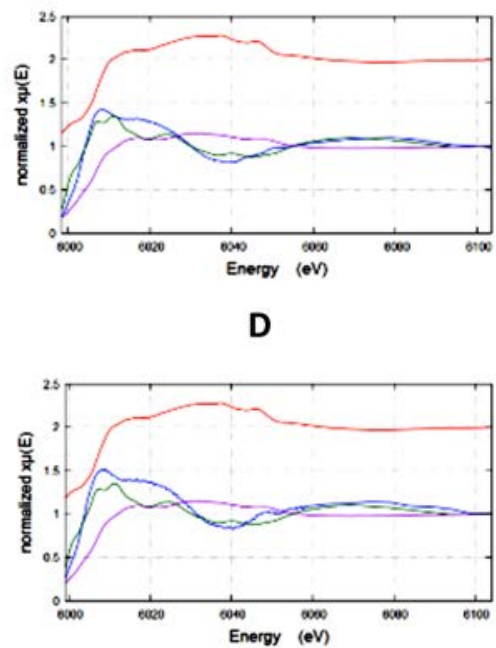

F

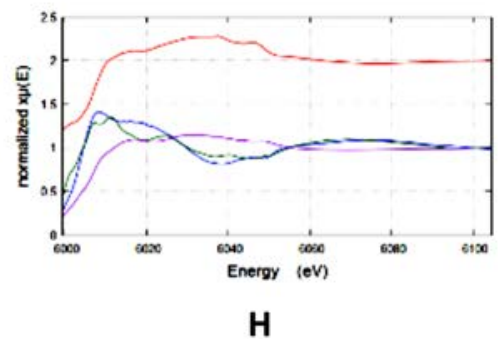

$\mathrm{K}_{2} \mathrm{Cr}_{2} \mathrm{O}_{7}:-\quad \mathrm{Cr}_{2} \mathrm{O}_{3}:-\quad \mathrm{CrO}_{3}:-\quad$ Sample : -

Figure 3. Cr K-edge XANES spectra of T. angustifolia shoot treated with 1, 5, 10, and 20 $\operatorname{ppm} \mathrm{Cr}(\mathrm{A}, \mathrm{C}, \mathrm{E}$, and $\mathrm{G})$ and root treated with $1,5,10$, and $20 \mathrm{ppm} \mathrm{Cr}(\mathrm{B}, \mathrm{D}, \mathrm{F}$, and $\mathrm{H})$. 
cants in veins, $S$. alfredii can accumulate $\mathrm{Zn}$ not only in its epidermis or mesophyll but also in the center part of its leaf vein. ${ }^{15}$

EtOAcThe efficiency of heavy metal translocation from root to shoot is affected by various processes such as symplast uptaking by root, root sequestration, xylem loading and xylem unloading, as well as heavy metals uptaking by foliar cells. Researchers have found that increased xylem loading is the main factor affecting absorption and translocation of heavy metal from root to shoot; as shown in increasing uptake of $\mathrm{Zn}$ and $\mathrm{Cd}$ by $\mathrm{S}$. alfredii, Solanum melongena, and Solanum torvum. ${ }^{14,20}$ The xylem loading capacity of heavy metal hyperaccumulator plants is higher than in non-hyperaccumulator plants. ${ }^{14,20}$ Hyperaccumulator plants also have special mechanisms to tolerate high concentration of heavy metals in tissue by using low-molecular-weight ligands, small metal-binding proteins such as histidine, organic acids, phytochelatine, metalothionine in the sequestration, transport, and accumulation of heavy metals. ${ }^{21}$

EtOAcCr(III) was the $\mathrm{Cr}$ species found to be accumulated in root and shoot of $T$. angustifolia in this study. Other researchers have found similar results in which $\mathrm{Cr}$ (III) was detected and accumulated in the root, stem and leaf of Parkinsonia acculeta, Convolvulus arvensis and Medicago truncatula. $^{22,23}$ Results from this study suggest that $\mathrm{Cr}(\mathrm{VI})$ may be reduced to $\mathrm{Cr}(\mathrm{III})$ in the root zone (rhizosphere). This zone creates a microenvironment for microorganisms; additionally, it has been found that roots release exudates that have the ability to reduce $\mathrm{Cr}(\mathrm{VI})$ to $\mathrm{Cr}(\mathrm{III})$ by adsorption. Biological activity in the rhizosphere and the availability of root exudates will affect heavy metal bioavailability. ${ }^{24}$ Among the microbial communities found in the root zone are Fe-oxidizing bacteria. These bacteria can form iron oxide plaques around wetland plant roots. Another study found that $\mathrm{Cr}$ can bind with ferro $(\mathrm{Fe})$ and $\mathrm{Mn}$ by forming a complex bond then become reduced to its trivalent form. ${ }^{25}$ Plant species have different mechanisms to reduce $\mathrm{Cr}$ (VI) to $\mathrm{Cr}(\mathrm{III})$ within the plant. In Trifolium brachycalycium, Atriplex canescence $G$. pseudochina and $S$. alfredii, $\mathrm{Cr}(\mathrm{VI})$ is reduced to $\mathrm{Cr}(\mathrm{V})$ then further reduced to $\mathrm{Cr}(\mathrm{III})$, or $\mathrm{Cr}(\mathrm{VI})$ is directly reduced to Cr(III). ${ }^{14,15,26}$

EtOAcHyperaccumulator plants may develop different mechanisms applicable in the phytoremediation process. In this study, T. angustifolia tolerated $\mathrm{Cr}(\mathrm{VI})$ by reducing it to $\mathrm{Cr}$ (III) in the rhizosphere. Absorption of $\mathrm{Cr}$ (III) occurred via roots then transported in the root to the xylem. $\mathrm{Cr}$ (III) may have been distributed via the symplastic system into the cytoplasm and accumulated in the vacuole. $\mathrm{Cr}$ (III) in an organic complex may be translocated to the shoot via the xylem apoplastic system. Therefore, results of this study suggest that $T$. angustifolia has the posssibility of developing phytoextraction mechanisms which are recognized in the phytoremediation process. Phytoextraction is the plant's ability to uptake contaminants and translocate them to aboveground parts of the plant. ${ }^{27}$

\section{Conclusions}

EtOAcResults of this study found that $\mathrm{Cr}$ in the form of $\mathrm{Cr}$ (III) was detected in almost all parts of T. angustifolia root and shoot. Overall, the patterns of $\mathrm{Cr}$ distribution and speciation observed suggest that $T$. angustifolia in this study did not have a mechanism to reduce $\mathrm{Cr}(\mathrm{VI})$ to become Cr(III) inside the plants, but T. angustifolia has the posssibility to develop phytoextraction mechanism by translocating $\mathrm{Cr}$ (III) to above parts of the plant.

\section{References}

1. USEPA. National Priorities List (NPL) Sites with fiscal year 1982-2003, Records of Decision (RODs). USEPAJune 2003, Office of Emergency and Remedial Response, (OERCLIS). USEPA. 2003. Available from: http:/www.epa.gov/superfund/sites/npl/

2. Dhal B, Thatoi HN, Das NN, Pandey BD. Chemical and microbial remediation of hexavalent chromium from contaminated soil and mining/metallurgical solid waste: a review. J Hazard Mater 2013;250-251:272-91.

3. Caravanos J, Gutierrez LH, Ericson B, Fuller R. A comparison of burden of disease from toxic waste sites with other recognized public health threats in India, Indonesia and the Philippines. J Heal Pollut 2014;4:2-9.

4. Ministry of Industry RI. Pertumbuhan Industri Logam Ditargetkan. Ministry of Industry, Republik Indonesia. 2012. Available from: http://www.kemenperin.go.id/artikel/4360/PertumbuhanIndustri-Logam-Ditargetkan-7

5. Suresh B, Ravishankar GA. Phytoremediation: a novel and promising approach for environmental cleanup. Crit Rev Biotechnol 2004;24:97124.

6. Chandra-Sekhar K, Kamala C, Chary N, Anjaneyulu Y. Removal of heavy metals using a plant biomass with reference to environmental control. Int J Miner Process 2003;68:37-45.

7. Rascio N, Navari-Izzo F. Heavy metal hyperaccumulating plants: How and why do they do it? And what makes them so interesting? Plant Sci 2011; 180:169-81.

8. Bose S, Vedamati J, Rai V, Ramanathan AL. Corrigendum to: Metal uptake and transport by Typha angustata L. grown on metal contaminated waste amended soil: An implication of phytoremediation. Geoderma 2008; 146:400.

9. Sasmaz A, Obek E, Hasar H. The accumulation of heavy metals in Typha latifolia L. grown in a stream carrying secondary effluent. Ecol Eng 2008;33:27884.

10. Essington ME. Soil and water chemistry: An integrative approach [Internet]. 2nd ed. CRC Press; 2015. $656 \mathrm{p}$.

11. Ravel B, Newville M. ATHENA, ARTEMIS, HEPHAESTUS: data analysis for X-ray absorption spectroscopy using IFEFFIT. J Synchrotron Radiat 2005;12:537-41.

12. Samantaray S, Rout GR, Das P. Role of chromium on plant growth and metabolism. Acta Physiol Plant 1998;20:20112.

13. McManus HA, Seago Jr JL, Marsh LC. Epifluorescent and histochemical aspects of shoot anatomy of Typha latifolia L. and Typha glauca Godr. Ann Bot 2002;90:489-93.

14. Lu L, Tian S, Zhang J, et al. Efficient xylem transport and phloem remobilization of $\mathrm{Zn}$ in the hyperaccumulator plant species Sedum alfredii. New Phytol 2013;198:721-31.

15. Mongkhonsin B, Nakbanpote W, Nakai I, et al. Distribution and speciation of chromium accumulated in Gynura pseudochina (L.) DC. Environ Exp Bot 2011;74:56-64.

16. Feng H, Qian Y, Gallagher FJ, et al. Lead accumulation and association with Fe on Typha latifolia root from an urban brownfield site. Environ Sci Pollut Res Int 2013;20:3743-50.

17. Lyubenova L, Pongrac P, Vogel-Mikuš $K$, et al. Localization and quantification of $\mathrm{Pb}$ and nutrients in Typha latifolia by micro-PIXE. Metallomics 2012;4:333.

18. Chen YL, Hong XQ, $\mathrm{He} \mathrm{H}$, et al. Biosorption of $\mathrm{Cr}$ (VI) by Typha angustifolia: Mechanism and responses to heavy metal stress. Bioresour Technol 2014;160:89-92.

19. Kötschau A, Büchel G, Einax JW, et al. Mapping of macro and micro elements in the leaves of sunflower (Helianthus 
annuus) by laser ablation-ICP-MS. Microchem J 2013;110:783-9.

20. Mori S, Uraguchi S, Ishikawa S, Arao T. Xylem loading process is a critical factor in determining $\mathrm{Cd}$ accumulation in the shoots of Solanum melongena and Solanum torvum. Environ Exp Bot 2009;67:127-32.

21. Teixeira J, Ferraz P, Almeida A, et al. Metallothionein multigene family expression is differentially affected by Chromium (III) and (VI) in Solanum nigrum L. plants. Food Energy Secur 2013;2:130-40.

22. Montes MO, Peralta-Videa JR, Parsons $\mathrm{JG}$, et al. Spectroscopic determination of the toxicity, absorption, reduction, and translocation of $\mathrm{Cr}(\mathrm{VI})$ in two Magnoliopsida species. Int Phytoremediation 2013;15:168-87.

23. Zhao Y, Parsons JG, Peralta-Videa JR, et al. Use of synchrotron- and plasmabased spectroscopic techniques to determine the uptake and biotransformation of chromium(III) and chromium(VI) by Parkinsonia aculeata. Metallomics 2009;1:330-8.

24. Kangwankraiphaisan T, Suntornvongsagul K, Sihanonth $\mathrm{P}$, et al. Influence of arbuscular mycorrhizal fungi (AMF) on zinc biogeochemistry in the rhizosphere of Lindenbergia philippensis growing in zinc-contaminated sediment. Biometals 2013;26:489-505.

25. Cheng SF, Huang CY, Tu YT, Chen JR. Cr-removal efficiency as affected by the Cr-bonding fractionation in soil treated with trivalent and hexavalent chromium. Int J Appl Sci Eng 2012;10:319-31.

26. Sawalha MF, Gardea-Torresdey JL, Parsons JG, et al. Determination of adsorption and speciation of chromium species by saltbush (Atriplex canescens) biomass using a combination of XAS and ICP-OES. Microchem J 2005;81:122-32.

27. Greipsson S. Phytoremediation. Nat Educ Knowl 2011;3:7. 